\title{
Full mouth rehabilitation on the patient with severe tooth wear and tooth fracture using reestabilishment of occlusal vertical dimension
}

\author{
Ho-Sun Lee, Se-Jin Joo, Soo-Yoon Jin, Dong-Wan Kang, Gyeong-Je Lee* \\ Department of Prosthodontics, School of Dentistry, Chosun University, Gwangju, Republic of Korea
}

\begin{abstract}
Severe dental attrition causes pathological changes of the tooth, imbalanced occlusion, and functional and aesthetic complications and can also result in a decrease in occlusal vertical dimension that can incur temporomandibular joint and muscular complications. Before restoring the vertical dimension with full-mouth prosthetic restorations, it is important to determine the amount of vertical lifting through complete diagnosis. In this study, a 59 year-old male patient with generalized attrition and fracture of teeth was treated with full-mouth zirconia prosthetic restoration in order to recover vertical dimension and aesthetics. Through the analysis of physiologic rest position and inter-canine distance, the treatment was planned for lifting $3 \mathrm{~mm}$ in vertical dimension. Interim crown were fabricated after full-mouth wax up, having the patient use for 6 months. The final monolithic and bilayered zirconia restorations were completed. The patient showed satisfaction in function and aesthetics for 18 months of follow-up since delivering the final restorations. (J Dent Rehabil Appl Sci 2016;32(3):224-31)
\end{abstract}

Key words: dental attrition; full-mouth prosthetic restoration; zirconia; vertical dimension

\begin{abstract}
서론
치아의 마모는 평생에 걸쳐 조금씩 진행되는 생리적 마 모와 과도하게 발생하는 병적인 마모로 구분할 수 있다. 과도한 치아의 마모는 치수의 병적 변화, 교합 불균형, 기 능적 및 심미적 문제를 야기할 수 있고 또한 수직고경의 감소를 가져올 수 있다. 또한 감소된 수직고경은 악관절 및 저작근의 문제를 일으킬 수 있다.

과도한 마모에 의한 수직고경의 감소에는 상반된 의견 이 존재한다. Dombrady, Tallgren 등 ${ }^{2}$ 은 보철물의 존재, 환경 등에 의해 안정위는 변할 수 있다고 하였다. 그에 반 해 $\operatorname{Dawson}^{3}$ 은 마모가 일어났을 때 치조 돌기가 감소된 치아의 수직 고경만큼 신장되기 때문에 원래의 수직 안 면 고경은 변하지 않는다고 하였고, 만일 수직 고경을 바 꿔야 한다면, 적절한 심미와 기능적 결과를 얻을 수 있는
\end{abstract}

*Correspondence to: Gyeong-Je Lee

Assistant Professor, Department of Prosthodontics, School of Dentistry, Chosun University, 303 Pilmun-daero, Dong-gu, Gwangju, 61452, Republic of Korea Tel: +82-62-220-3827, Fax: +82-62-232-7776, E-mail: Ikj1998@chosun.ac.kr Received: July 8, 2016/Last Revision: July 26, 2016/Accepted: August 3, 2016
정도에서 가장 적게 고경을 변경시키는 치과 치료를 시 행해야 한다고 강조하였다. Dawson의 의견과 같이 마모 에 의한 수직고경의 변화가 없더라도 보철 수복시 수복 에 필요한 적절한 악간 공간 및 유지를 위한 치관의 높이 를 확보하고, 적절한 전치간의 관계를 확보하기 위해 수 직고경을 높여야 할 경우가 있다.

수직고경을 회복시키는 전악 보철 수복을 할 때는 정 확한 진단과 분석을 통해 적절한 수직 고경 거상량을 결정하고 적절한 중심위를 채득하는 것이 중요하다. Moneteith ${ }^{4}$ 는 수직고경 증가로 인해 자유로 공간이 침범 되면 턱관절 질환과 치아의 정출, 함입, 보철물의 파절 등 여러 가지 문제점이 생길 수 있다고 하였다.

본 증례는 전반적인 치아의 마모와 파절을 보이는 말 단비대증을 않고 있는 59세 남자 환자이다. 말단비대증 은 성장 호르몬이 과잉 분비되어 신체 말단의 뼈가 과도 
하게 증식함으로써 손, 발, 코, 턱 등의 비대가 나타나는 만성질환이다. 말단비대증 환자의 악안면 영역의 증상으 로는 혀와 입술의 비대 및 수면 무호흡증을 일으킬 수 있 는 구개음 조직(palatal tissue)의 비대가 나타나고 치아 위치의 변화로 인한 부정교합으로 인해 하악 턱의 전돌 (prognathism) 및 개교합이 나타날 수 있다. ${ }^{5}$ 하지만 경 조직과 연조직의 변화가 점진적으로 이루어지기 때문에 성장기에서는 진단이 어렵고 늦어질 수 있다. ${ }^{6,7}$

이 환자의 수직고경을 회복시켜 주기 위해 전악 지르 코니아 보철 수복을 하였고 최종 보철 후 1년 6개월 경과 관찰 결과 심미적, 기능적으로 만족을 만한 결과를 보였 기에 보고하고자 한다.

\section{증례보고}

본 증례는 59세 남자 환자로서 전반적인 치아의 마모 와 파절을 나타낸 환자로서 이가 많이 닪아서 전체적으 로 치료하고 싶다는 주소로 본원에 내원하였다. 전신질 환으로는 2010년 갑상선암 수술 후 방사선 치료를 받았 었고 말단비대증을 않고 있었다. 임상 검사 결과 전반적 인 치아의 마모 및 파절로 인해 교합수직고경의 감소가 관찰되었고 상악 우측 제 2 소구치는 상실되어 있는 상태 였다(Fig. 1). 전체적으로 교합면의 상아질이 노출되어 지 각과민 증상을 호소하였고 \#12,11 도재전장관의 설면 도재파절이 관찰되었다. 전치부 수평피개는 $3 \mathrm{~mm}$, 수 직피개는 $2 \mathrm{~mm}$ 이고 상하악 정중선은 불일치하였으며,
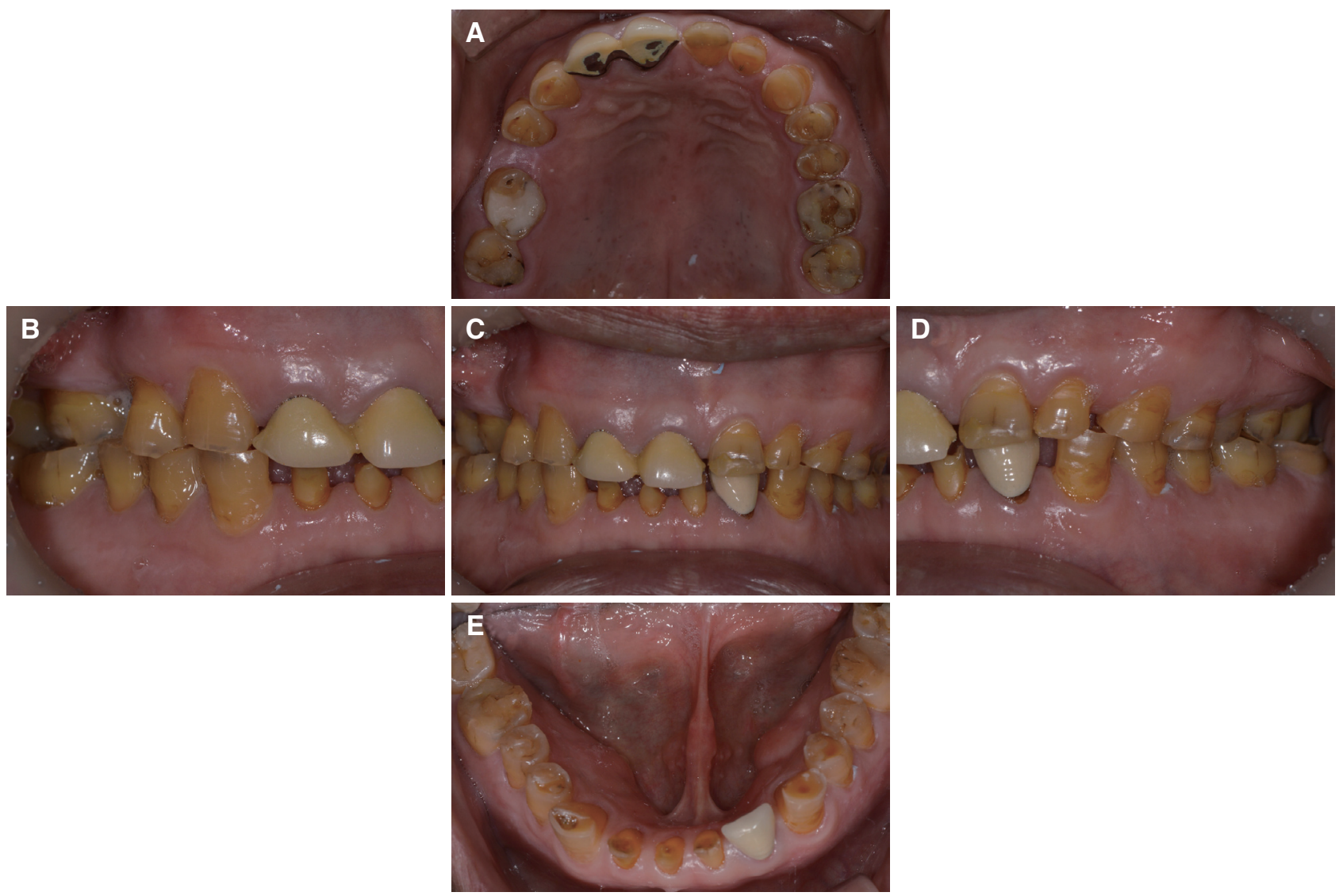

Fig. 1. Intra-oral status in the initial examination. (A) Maxillary occlusal view, (B) Right lateral view, (C) Frontal view, (D) Left lateral view, (E) Mandibular occlusal view. 
하악이 우측으로 $3 \mathrm{~mm}$ 가량 편위를 나타냈다. \#37과 \#46, 47은 반대교합(cross bite)이였다. 구외검사 결과 사 각형의 안모를 가지고 있었고 발달된 양쪽 교근이 관찰 되었다. 최대 개구량 $40 \mathrm{~mm}$ 로서 하악 운동의 장애 및 제 한은 보이지 않았으나 파노라마 방사선상 양측 하악 과 두의 교모 소견 및 하악각의 과증식을 나타냈다(Fig. 2). 말단비대증이 있었지만 골격적으로 상하악의 관계는 1 급 교합이었다. 말단 비대증 환자에게서 나타나는 측모 방사선 사진상 확장된 sella turcica의 영역을 확인할 수 있었다(Fig. 3).

진단모형을 제작하고 안궁이전을 시행하여 교합기에 부착하였다. 수직고경 거상량을 결정하기 위해 안정위시 악간 공극 측정, 발음, 상하악 견치의 치은연 사이의 거리 등을 검사하였다. 치은전정간의 거리는 $36 \mathrm{~mm}$, 견치간 치은연 사이 거리는 $15 \mathrm{~mm}$ 였다. 상하악 전치의 마모로 인해 짧은 치관이 관찰되었다. 측두하악관절의 회전 운 동 범위 및 구강 주위 근육의 적응도, 생리적 안정위, 보 철 수복을 위한 공간, 절치 노출도 등을 고려하여 견치간 거리를 기준으로 약 $3 \mathrm{~mm}$ 거상하기로 하였다.

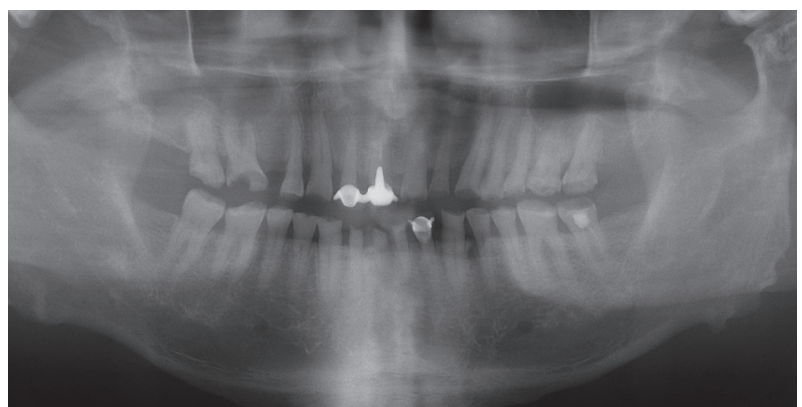

Fig. 2. Pre-treatment panoramic radiograph.
보철물은 구치부의 경우 금전장관을 권유드렸으나 환 자가 심미적인 치아 색깔의 재료를 강하게 원하여 구치 부는 단일 구조 지르코니아로 결정하였고, 전치부는 환 자의 강한 심미성 요구를 고려하여 단일 구조 지르코니 아가 아닌 지르코니아 코어 제작 후 도재로 축성하여 제 작하기로 하였고 보철 완성 후 도재 파절 방지를 위해 교 합안정장치를 제작해 주었다.

진단 왁스업 시행 후 1 차 임시치관을 제작하였다. 치아 삭제 후 임시치관을 장착하여 3개월간 사용하였다(Fig. $4,5)$. 이후 2차 임시치관을 제작하였는데 고딕 아치 트레 이싱(Fig. 6)을 이용한 정확한 중심위 재측정 및 1차 임시 치관의 파절, 미반응 모노머로 인한 변색 등이 그 이유이 다. 2차 임시치관을 3 개월간 사용하는 동안 환자는 잘 적 응하였고 심미적, 기능적으로 문제점이 없었다(Fig. 7).

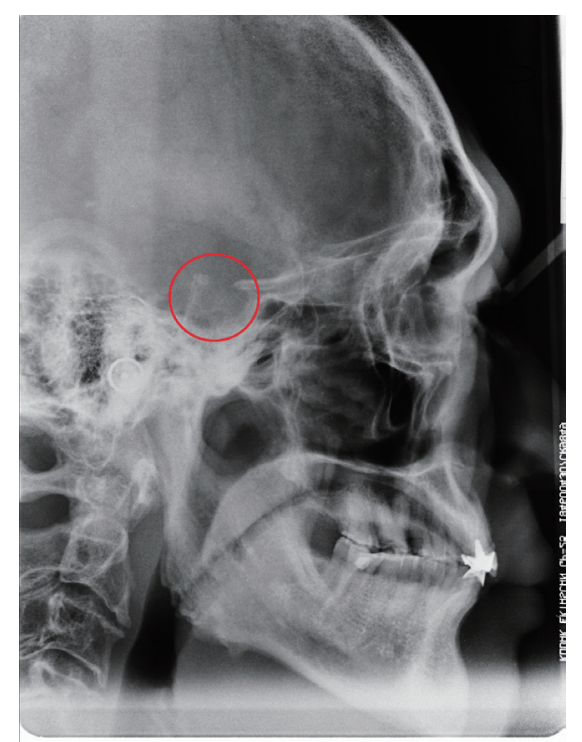

Fig. 3. Lateral skull radiograph shows enlarged sella turcica.

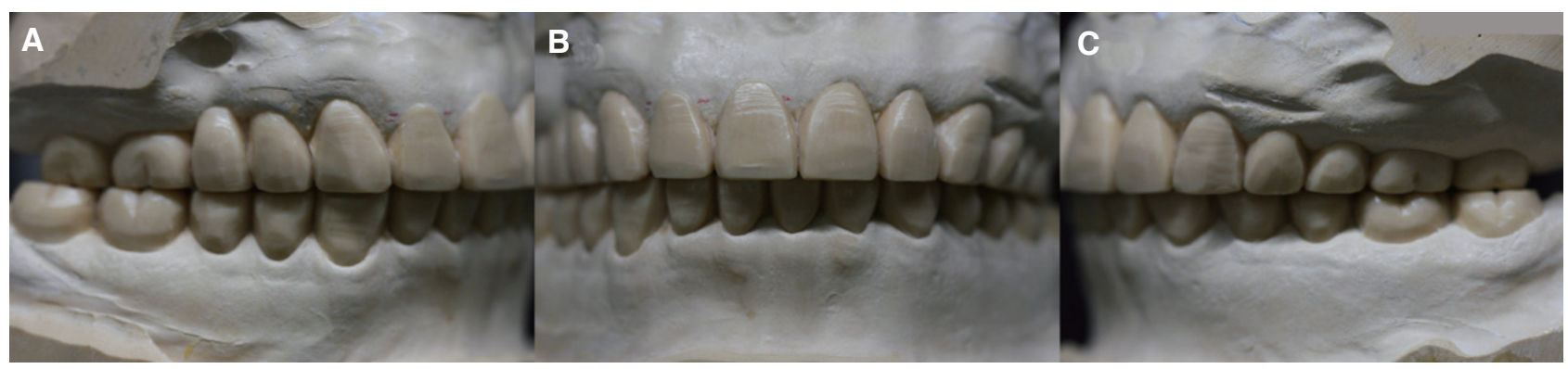

Fig. 4. Diagnostic wax up model with new occlusal vertical dimension. (A) Right lateral view, (B) Frontal view, (C) Left lateral view. 


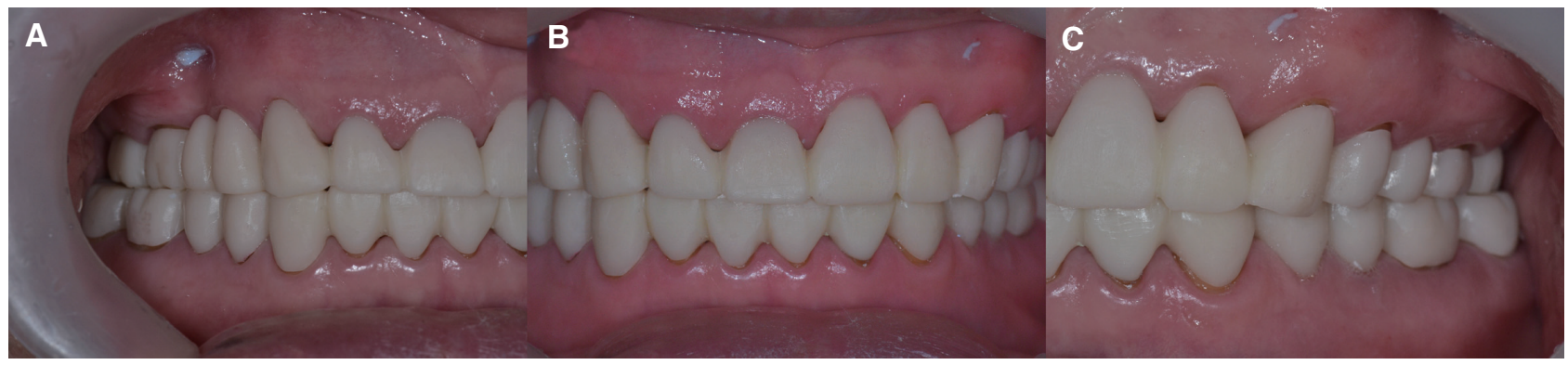

Fig. 5. 1st provisional restoration. (A) Right lateral view, (B) Frontal view, (C) Left lateral view.

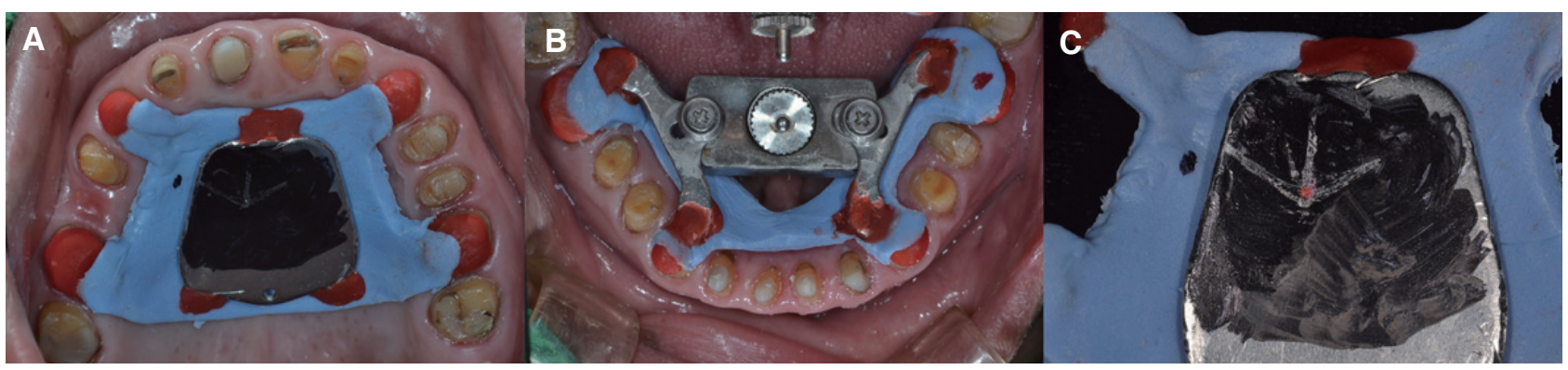

Fig. 6. Gothic arch tracing. (A) Gothic arch tracer on maxillary arch, (B) Gothic arch tracer on mandibular arch, (C) Gothic arch apex represented centric relation.

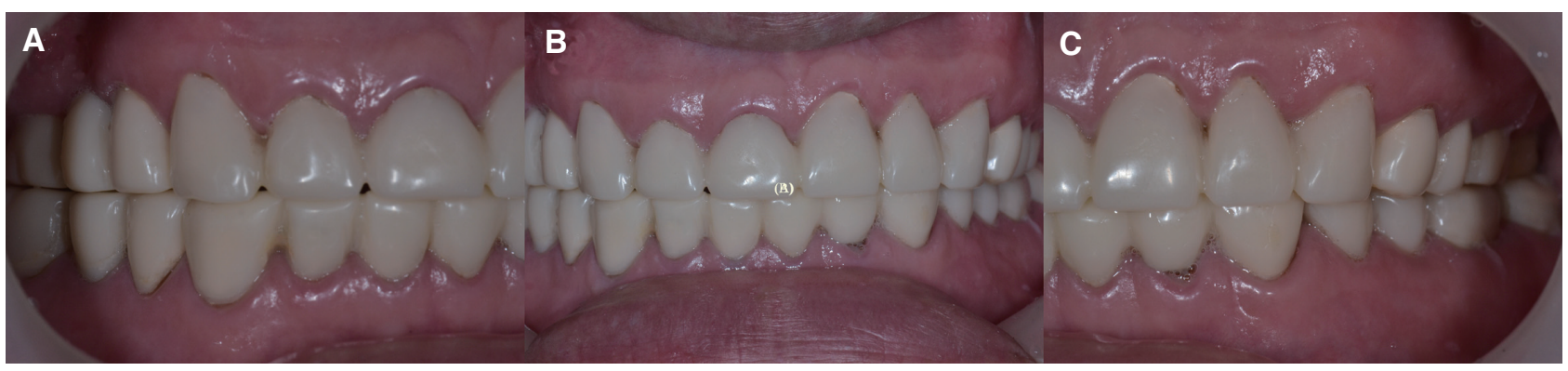

Fig. 7. 2nd provisional restoration. (A) Right lateral view, (B) Frontal view, (C) Left lateral view.

지대치 인상채득은 개인트레이를 제작하여 이중 압 배 술식 및 이중 혼합법을 사용하여 인상을 채득하였 다. 인상재로는 Poly vinylsiloxane 인상재(AQUASIL $\mathrm{ULTRA}^{\circledR}$, Dentsply, Milford, USA)를 사용하였다. 환 자가 적응한 임시치관의 고경 및 교합관계를 그대로 옮 겨주기 위하여 임시치관을 수직 정지점(vertical stop) 으로 poly vinylsiloxane 제재의 교합인기제(Exabite ${ }^{\circledR}$, GC corp., Tokyo, Japan)를 이용하여 교합을 채득하였 다. 환자의 하악 운동 및 과로각을 재현하기 위하여 임시 보철물 상에서 ARCUSdigma2 ( $\mathrm{KaVo}$ Dental $\mathrm{GmbH}$, Biberach, Germany)를 사용하였으며 여기에서 측정된
값으로 교합기 과로경사각을 조절하였다. 또한 아크릴 릭 레진(Pattern Resin, GC Co.)을 이용하여 맞춤형 전 방유도판을 제작하였다. 임시보철물 모형과 작업 모형 을 반조절성 교합기(Protar evo 5, $\mathrm{KaVo}$ Dental $\mathrm{GmbH}$, Biberach, Germany)에 크로스 마운팅을 시행하였다. 최 종 왁스업은 전방운동시 상악 중절치 및 측절치의 균일 한 가이드 부여 및 구치부에서 $1 \mathrm{~mm}$ 정도 이개되도록 하 였고 측방운동시에는 견치유도를 부여하였다. 지르코니 아 코핑 후 도재 축성한 전치부의 도재 파절 가능성을 고 려하여 추후 교합안정장치를 제작하여 사용하기로 하였 다. 
왁스업 모형을 스캔하여 CAD 프로그램을 이용해 되 깍기(cut-back)를 시행하였다(Fig. 8). 전치부 지르코니아 코핑과 구치부 단일 구조 지르코니아 시적 후 최종 보철 물을 완성하였다. 2 개월의 임시합착기간 동안 모든 치아 의 균일한 교합접촉과 측방운동시 견치유도가 되도록 조 정하였다. 최종 합착시 시멘트의 누수가 없음을 확인하 고 지르코니아 내면에 샌드블러스트 처리 및 지르코니아
프라이머(Zirconia liner, Sun medical Co., Shiga, Japan) 처리 후 레진 시멘트(RelyX Unicem, 3M, St. Paul, USA) 로 영구합착하였다(Fig. 9). 최종 마무리 후 교합안정장 치를 제작하여 보철물 파절이 발생하지 않도록 하였다. 1 년 6개월의 경과 관찰기간동안 환자는 불편감 없이 심미 적, 기능적으로 만족스러운 결과를 나타냈다.

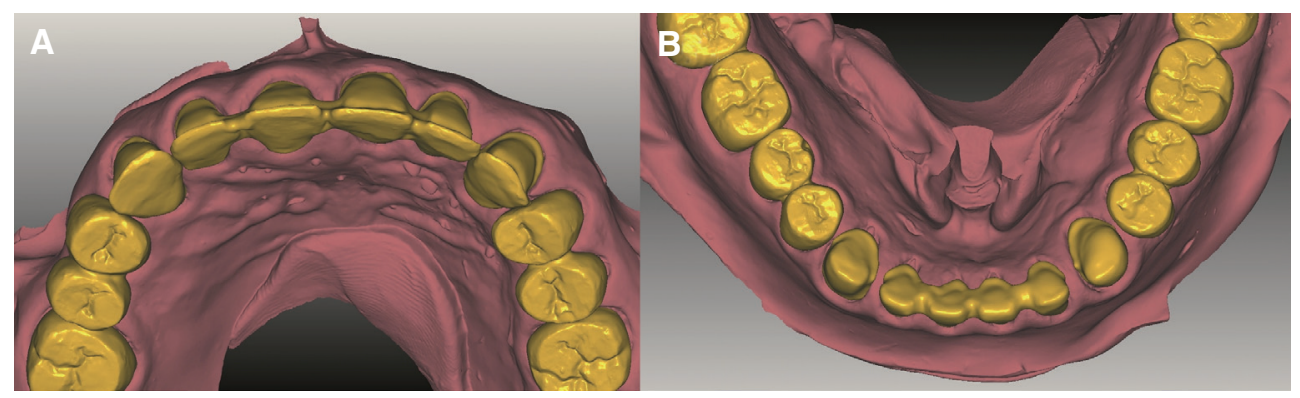

Fig. 8. Cut-back zirconia coping design in CAD/CAM software. (A) Maxillary occlusal view, (B) Mandibular occlusal view.
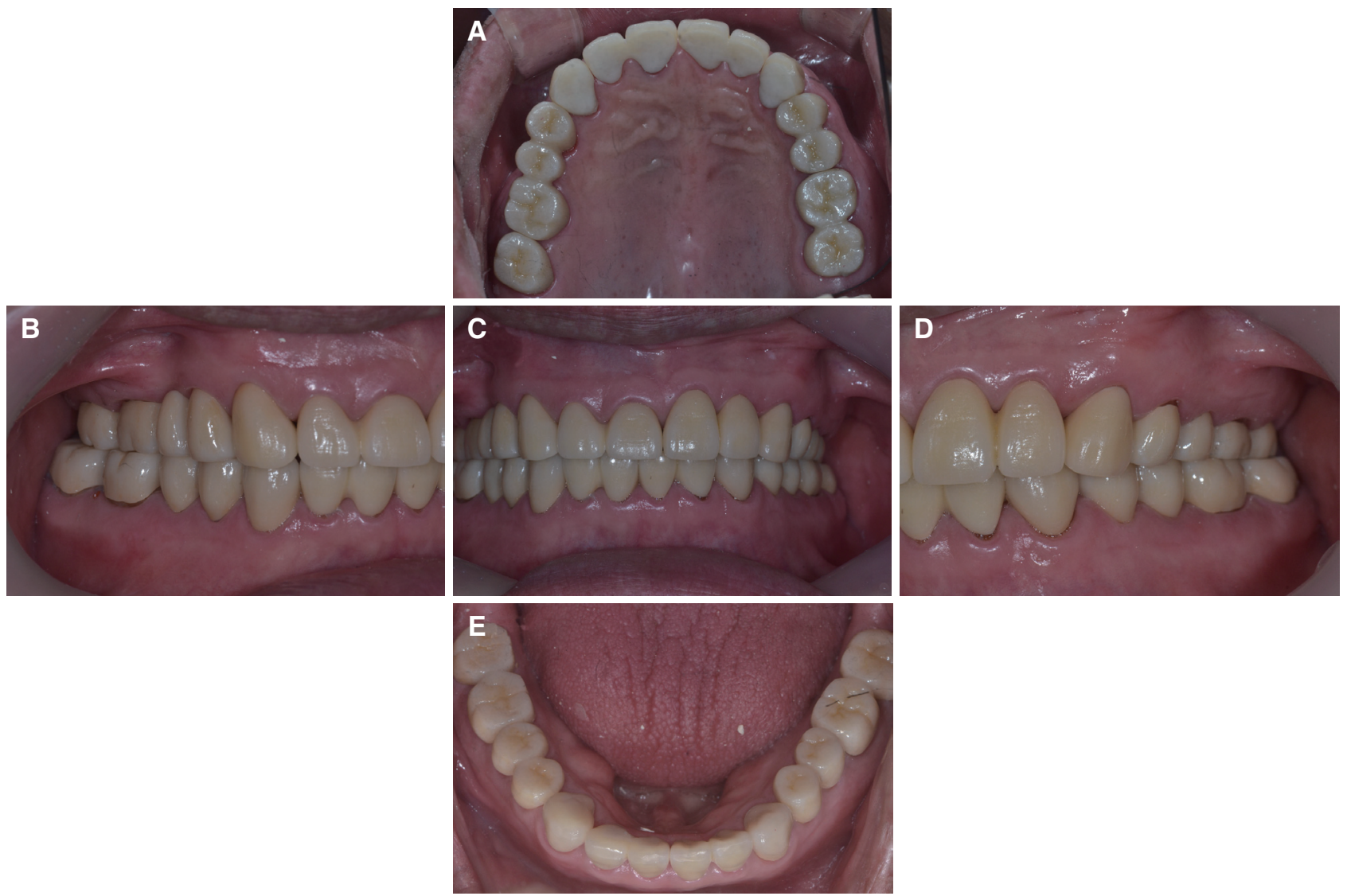

Fig. 9. Final prosthesis. (A) Maxillary occlusal view, (B) Right lateral view, (C) Frontal view, (D) Left lateral view, (E) Mandibular occlusal view. 


\section{고찰}

전악보철수복은 광범위한 비가역적 처치를 수반하므 로 정확한 진단 및 치료계획 수립이 필요하다. 실제 전신 질환과 관련된 전악 보철 수복의 금기증의 하나로 진행 중인 말단비대증이 보고되고 있다. ${ }^{8}$ 이는 진행중인 말단 비대증 환자에서 악골의 과성장에 의한 심한 하악의 전 돌로 인한 3급 부정교합 ${ }^{6}$ 및 개교합증(apertognathia) ${ }^{9}$ 등 의 발생이 빈번하기 때문이다. 하지만 본 환자는 59세의 중장년층 환자로서 말단비대증의 진행이 멈춘 상태이고 1 급 교합을 나타내었으므로 전악보 복을 시행한 경우이 다. 실제 Markovic와 Trisovic ${ }^{10}$ 에 연구에 따르면 39명의 말단비대증 환자를 조사한 결과 9명 $(23 \%)$ 이 1급 교합을 나타내었다. 환자가 심한 치아의 마모로 인해 기능적인 저작 불편감 및 비심미성의 개선을 강하게 원하시어 전악 보철수복을 진행하였다.

수직고경을 거상하기 위해서는 진단모형을 통해 정확 한 진단과 분석을 하는 것이 반드시 중요하다. 수직고 경 거상량을 결정하는 방법으로는 안정위시 악간공극, ${ }^{11}$ "S" 발음을 이용한 closest speaking space 측정, " 12 " 발음을 이용한 안정위 공극 측정, ${ }^{13}$ 연하, Willis 법 ${ }^{14}$ 과 같 은 안모계측 등의 다양한 방법이 있다. 그동안 발표된 다 양한 증례를 통해 감소된 수직고경을 인위적으로 적절 히 증가시켰을 때 악관절과 저작근이 잘 적응될 수 있다 는 사실을 알 수 있다. 본 증례는 안정위 교합공극 및 상 하악 견치간 거리등을 이용하여 수직고경 거상량을 결정 하였다. $3 \mathrm{~mm}$ 의 수직고경 거상을 통해 환자의 교합을 재 설정하여 안정적이고 만족스러운 결과를 보였다. RiveraMorales와 Mohl ${ }^{15}$ 은 과도하게 수직고경을 증가시키지 않는다면 악관절계가 잘 적응할 수 있다고 하였고 적절 하게 증가시킨 수직고경이 악관절계에 해롭다는 과학적 증거는 없다고 하였다.

구치부 보철은 파절 가능성을 최소화하기 위해 단일 구조 지르코니아로 하였다. 그리고 교합조정 후 최종 합 착전에 표면을 고도로 부드럽게 마무리하는 것에 특별한 주의를 기울였다. $\mathrm{Oh}$ 등 $^{16}$ 에 따르면 세라믹 보철물의 경 도와 치아 법랑질 마모간에 강한 상관관계가 있다는 과 학적 근거는 없다고 하였다. 마모는 보철물의 미세구조 와 대합치와의 접촉면의 거칠기, 그리고 환경에 영향을 받는다고 하였고 표면을 부드럽게 마무리하고 glazing을 하는 것으로 대합치의 마모를 줄일 수 있다고 하였다.

최근 지르코니아 보철의 수명에 관한 연구에서, 2010
년 Ozkurt와 $\mathrm{Kazazo}^{17}$ 는 단일 구조 지르코니아의 5 년 생존율을 $98 \%$ 로 보고하였다. 그에 반해 지르코니아 코 핑 후 도재 축성시 파절은 6-25\%로 나타났다. ${ }^{18}$ 최종 보 철 완성 후에 보철물 파절 방지 및 안정된 결과를 유지하 기 위해 교합안정장치를 제작하여 사용하는 것이 필요하 다. ${ }^{19} \mathrm{Wood}^{20}$ 는 전악보철수복으로 새로 중심위를 형성하 여도 중심위는 계속 변화할 수 있기 때문에 주기적으로 점검 및 필요시 교합조정이 필요하다고 하였다. 본 증례 에서는 최종 보철물 장착 및 교합안정장치 사용 1년 6개 월 후에도 보철물의 파절 없이 안정된 교합을 나타냈다.

\section{결론}

본 증례에서는 심한 치아 마모 및 파절로 인해 수직고 경이 감소된 환자에서 안정위시 악간공극 측정 및 발음, 상하악 견치간 거리 평가 등을 이용해 진단분석을 시행 하여 $3 \mathrm{~mm}$ 교합거상하여 임시치관을 6 개월 이용 후 환 자가 잘 적응하는 것을 확인한 후 전악 지르코니아 보철 수복하였다.

최종 보철 마무리 후 보철물 파절을 방지하기 위해 교 합안정장치를 제작하여 사용하였고 약 1년 6개월간의 관 찰결과 교합이 안정적으로 유지되고 있고, 보철물의 파 절이 관찰되지 않았으며 심미적, 기능적으로 만족할 만 한 결과를 얻었기에 이에 보고하는 바이다.

\section{Achnowledgments}

이 논문은 2013년도 조선대학교 치과병원 학술연구비 의 지원을 받아 연구되었음.

\section{ORCID}

Ho-Sun Lee http://orcid.org/0000-0001-8793-8429

Se-Jin Joo http://orcid.org/0000-0002-1814-661X

Soo-Yoon Jin http://orcid.org/0000-0002-4910-0286

Dong-Wan Kang http://orcid.org/0000-0001-9455-4706

Gyeong-Je Lee http://orcid.org/0000-0002-3545-2280 


\section{References}

1. Dombrady L. Investigation into the transient instability of the rest position. J Prosthet Dent 1966;16: 479-90.

2. Tallgren A, Lang BR, Walker GF, Ash MM Jr. Changes in jaw relations, hyoid position, and head posture in complete denture wearers. J Prosthet Dent 1983;50:148-56.

3. Dawson PE. Functional occlusion from TMJ to smile design. 1st ed. Amsterdam; Elsevier; 2008. p. 114-22.

4. Monteith B. The role of the freeway space in the generation of muscle pain among denture wearers. J Oral Rehabil 1984;11:483-98.

5. Appleby DC, Cilento PA. Malocclusion secondary to acromegaly: a case report. Compendium 1993; 14:950-2.

6. Jadresic A, Banks LM, Child DF, Diamant L, Doyle FH, Fraser TR, Joplin GF. The acromegaly syndrome. Relation between clinical features, growth hormone values and radiological characteristics of the pituitary tumors. Q J Med 1982;51:189-204.

7. Dons RF, Rieth KG, Gorden P, Roth J. Size and erosive features of the sella turcica in acromegaly as predictors of therapeutic response to supervoltage irradiation. Am J Med 1983;74:69-72.

8. Counsil of Fixed Prosthodontic Professor. Fixed prosthodontics - principle and clinic. 1st ed. Seoul; DaehanNarae Publishing; 2012. p. 6.

9. Cohen RB, Wilcox CW. A case of acromegaly identified after patient complaint of apertognathia. Oral
Surg Oral Med Oral Pathol 1993;75:583-6.

10. Markovic M, Triscovic D. Some results of occlusal and metric analysis of acromegalic cases. Int J Orthod 1978;16:13-20.

11. Mohamed SE, Christensen LV. Mandibular reference positions. J Oral Rehabil 1985;12:355-67.

12. Siverman MM. The speaking method in measuring vertical dimension. 1952. J Prosthet Dent 2001;85: 427-31.

13. Turrell AJ. Clinical assessement of vertical dimension. J Prosthet Dent 1972;28:238-46.

14. Willis FM. Features of the face involved in full denture prosthesis. Dent Cosmos 1935;77:851-4.

15. Rivera-Morales WC, Mohl ND. Relationship of occlusal vertical dimension to the health of the masticatory system. J Prosthet Dent 1991;65:547-53.

16. Oh WS, Delong R, Anusavice KJ. Factors affecting enamel and ceramic wear: a literature review. J Prosthet Dent 2002;87:451-9.

17. Ozkurt Z, Kazazo lu E. Clinical success of zirconia in dental applications. J Prosthodont 2010;19:64-8.

18. Bachhav VC, Aras MA. Zirconia-based fixed partial dentures: a clinical review. Quintessence Int 2011; 42:173-82.

19. Sato S. Hotta TH, Pedrazzi V. Removable occlusal overlay splint in the management of tooth wear: a clinical report. J Prosthet Dent 2000;83:392-5.

20. Wood GN. Centric relation and the treatment position in rehabilitating occlusions: a physiologic approach. Part II: the treatment position. J Prosthet Dent 1988;60:15-8. 


\section{심한 치아 마모 및 파절 환자의 수직고경거상을 동반한 전악 수복 증례}

\section{이호선, 주세진, 진수윤, 강동완, 이경제*}

조선대학교 치과대학 치과보철학교실

과도한 치아의 마모는 치아의 병적 변화, 교합 불균형, 기능 및 심미적 문제를 일으키며 악관절과 근육의 문제를 일으킬 수 있는 수직고경의 감소를 야기할 수도 있다. 수직고경의 감소가 발생한 경우, 전악보철수복을 통해 수직고경을 회복 시켜 주기 위해서는 정확한 진단이 중요하다. 본 증례는 59세 남성으로 전반적인 치아의 마모와 파절로 인한 수직고경의 감소 및 비심미성을 해결하기 위해 전악 지르코니아 보철 수복을 시행하였다. 생리적 안정위, 견치간 거리 등을 분석하여 수직고경을 $3 \mathrm{~mm}$ 거상하기로 하였고 전악 왁스업 후 임시치관을 제작하여 6개월동안 사용한 뒤 이를 이용하여 지르코 니아 최종 보철을 완성하였다. 1년 6개월 경과 관찰하여 만족스러운 결과를 얻었기에 보고하는 바이다.

(구강회복응용과학지 2016;32(3):224-31)

주요어: 치아 마모; 전악 보철 수복; 지르코니아; 수직고경

*교신저자: 이경제

(61452)광주광역시 동구 필문대로 303 조선대학교 치과대학 치과보철과

Tel: 062-220-3827 | Fax: 062-232-7776 | E-mail: |kj1998@chosun.ac.kr

|접수일: 2016년 7월 8일 | 수정일: 2016년 7월 26일 | 채택일: 2016년 8월 3일 